\title{
The Gospel of Truth as the Gospel of the Saved Saviors
}

\section{Gnosis from Daily Life to Cosmic Enlightenment}

\author{
Jörgen Magnusson \\ Department of humanities and social sciences, Mid Sweden university \\ Jorgen.magnusson@miun.se
}

\begin{abstract}
In this article, I present a new reading of the Gospel of Truth, Nag Hammadi Codex I.3. Although Gnostics often have been described as taking part in the Godhead, the consequences are understudied. According to my analysis, the knowers are not subordinated to, but on equal footing with the Savior. Here, I draw the attention to some gradual processes. The Savior understands more and develops in the encounter with the need of others, saved as well as not yet saved. Through mission and deepening insight, the knowers more and more actualize themselves as Saviors, thereby embodying divinity. The consequence of this is a gradual actualization of the godhead itself. As the knowers gradually are enlightened and their divine nature disclosed, the insight of the godhead accordingly evolves. Thus, mutuality is a key concept. The Saviors cannot actualize their own nature without first having been saved and then they need to save others. The godhead, Saviors and saved are interdependent. The godhead evolves into actualized divinity through the evolving enlightenment of all its parts. Thus, the daily-life encountering with others is of fundamental importance on all levels, from the individual to the cosmic.
\end{abstract}

\section{Keywords}

Gospel of Truth - soteriology - Christology - Godhead - enlightenment 
The purpose of this article is to analyze an aspect of self-identification that appears in the Gospel of Truth (NHC I.3). ${ }^{1}$ As far as I know, the argument this article makes lacks predecessors. Hence, the references are very limited. Stating the results in advance, I claim that the author of the Gospel of Truth saw those who had been saved by knowledge as saviors who, in turn, were predestined to save others, thereby actualizing their identities as "saved saviors." In this way, I aim to describe a hitherto overlooked aspect of soteriology that also has a bearing on how we view the Godhead in general. I assert that we are not dealing with an identification with Christ that makes Christ superior to the imitators of Christ. Rather, the knower becomes a savior on equal footing with Christ. The Gospel of Truth expresses a high Christology. The Son is the expressive side of the Godhead. Therefore, the knower, if equal to Christ, is equal to God. At the end of the article, I briefly draw the attention to how the results might have an impact on our view on previous research.

Most studies on the Gospel of Truth are intertextually orientated, which is understandable indeed. To begin with, it is difficult to pinpoint the general message of the text. In the early days, Till claimed that the Gospel of Truth was hard to interpret due to a bad translation from Greek to Coptic. ${ }^{2}$ A different opinion was voiced by Fecht, who held that the Gospel of Truth was carefully composed and should be analyzed with conventions of ancient Egyptian poetry in mind. ${ }^{3}$ However, Fecht never reached a conclusion on the general message of the text. In 1966, Nagel suggested that the Gospel of Truth could be best interpreted by assuming it was translated from Syriac to Coptic, but it remains unclear what this broader view of the text would have been. ${ }^{4}$

In 2006, I devoted much energy to solving philological problems in the text. ${ }^{5}$ According to my investigations, many of those problems could be overcome by keeping in mind conventions of Greek rhetoric, which employs long elaborate sentences. To some extent, I took a position similar to Standaert, although

1 In NHC XI.2, we have some fragments of the Gos. Truth. But in this study, however, we do not discuss passages that are represented in codex XII. Thus, only NHC I.3 is referred to.

2 Till $195^{8}$.

3 Fecht 1961; 1962; 1963.

4 Nagel 1966.

5 Magnusson 2006. 
Standaert never worked on the Coptic text but on a French translation of the Gospel of Truth. ${ }^{6}$ As Stephen Emmel remarked when we worked on the Gospel of Truth from $2003^{-2005}$, it might be the most challenging text in the Nag Hammadi collection due to its elusive character. I suppose this is why many thematic works have paid more attention to broader religio-historical context of the Gospel of Truth rather than the intra-textual context of the text itself. ${ }^{7}$ The drawback of my earlier approach is quite the opposite. ${ }^{8}$ I focused on intratextual analysis, thus limiting a broader contextualization of the Gospel of Truth. This study aims to develop my work and pave the way for a future contextualization that is beyond the scope of this article.

Regarding the Christology of the Gospel of Truth, Arai's pioneering work of 1964 must be mentioned. ${ }^{9}$ However, the intra-textual focus that I employ in this study was impossible in the early days of research into the Gospel of Truth due to the many philological and hermeneutical problems that I touched upon briefly above. Thus, Arai's work does not have a great influence on my study. First, I introduce a passage that is central for our investigation. Then I briefly compare my interpretation of it with my interpretation of some other Valentinian texts, thereby formulating a hypothesis about the relationship between the parent of truth, Christ, and the idea of the knower that the Gospel of Truth advocates. After that, I follow a line of thought through some pages of the text in order to see whether the hypothesis helps us to decipher hitherto enigmatic passages.

\subsection{Terminology}

Some brief remarks on terminology are necessary. Frequently, I have used the word "Godhead" instead of God. It reflects my view that the dividing lines between God, Christ, and the church of the knowers are consciously blurred in the Gospel of Truth. Consequently, I adopt the term "Godhead," which is less related to the distinctions that are commonly related to God in many other forms of Christian thought.

I have also chosen to translate the Coptic neic) with "the Parent" instead of with "the Father," which is the common rendering, because I assert it more faithfully renders the view on the Godhead reflected in the Gospel of Truth. In 24.6-9 we read the following about the Godhead. "It/he restores them by bringing them back into the Father, into the Mother, Jesus of the infinity of

\footnotetext{
6 Standaert 1976.

7 E.g. Heldermann 1984; Tite 2009.

8 Magnusson 2006.

9 Arai 1964.
} 
sweetness!" Moreover, in 27.4-28.3 the metaphors bring to mind both the male and the female part of procreation, according to common views of antiquity. The Godhead is described as a mother in terms of a womb and as a male in terms of the active will to engender. ${ }^{10}$ Coptic lacks a word for "parent," so it seems like "Father" is often used in its place.

I am convinced that the Gospel of Truth is of Greek origin. Since Greek has a word for "parent," (yovev́s) it is most likely that the word for "parent" appeared in the original. If we take the Coptic audience into account, they must have been used to interpreting пєіळT sometimes as "Father" and sometimes as "Parent," depending on the context. The downside of using "Parent" instead of "Father" is that allusions to the New Testament and other texts might be less clear. However, I would say that the advantages of my way of translation far overweight the drawbacks. Only when I quote other translations is the term "Father" used.

\subsection{The Spreading of Knowledge}

Our point of departure is a scene in which a clash between the Savior and the demiurgical figure labeled Error is portrayed..$^{11}$

Through the knowledge he enlightened those who through oblivion were in darkness. He enlightened them, provided a way, and the way is the truth, which he taught them. For this reason, Error grew angry with him, persecuted him, became distressed by him, and was defeated by him when they nailed him to a tree, because he became a fruit of the knowledge of the Parent!12 Now, the fruit did not perish, because it was eaten. ${ }^{13}$

$10 \quad$ For an interesting discussion on these problems, see Good 1988.

11 тп入анн. Although "Error" is never labeled Saklas, Ialdabaoth, Samael, or the like, I hold there are good reasons to interpret it as a creatively modified demiurgical figure. It works on matter $2 \gamma_{\mathrm{H}}$ (Gos. Truth NHC I,3 17.14) and seems to be a creator divinity (17.18-21),

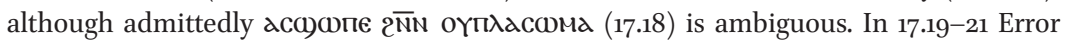
creates a beautiful substitute for truth. In Greek we have terms like космєाм or космікळ that fit well in a context in which a demiurgical figure is dealt with.

12 Gos. Truth NHC I,3 18.21b-26a is a long asyndetic construction. Of course, the manner of construing the relationship between the clauses is a matter of general interpretation. That the punchline should be at the end is probable, because it is a common phenomenon in Greek and Coptic rhetoric and attested on p. 19 27-20.6 as well.

13 Most translators have translated this: "It did not bring perishability, because it was eaten" or other wordings with basically the same meaning. From a grammatical point of view, however, it requires an emendation of the text, because мтатеко in 18.26b lacks an object and for this reason should be taken ingressively: "It did not enter a state of perishing, because it was eaten." My choice to go against other translations is guided by an inclination to avoid emendations and my opinion that the eternal and unbreakable nature of the 
Moreover, to those who ate it, whom he discovered in himself and who discovered him in themselves, it caused them to rejoice in its discovery!14

This passage can be translated in different ways, but the different options available do not fundamentally change the general sense of the pericope. Jesus has challenged Error by spreading knowledge to those who were unenlightened. Then the pericope continues with a description of the consequences of such a confrontation. Although the missionary of knowledge risks being killed, this would result in the destruction of the powers of darkness and maybe in the dethronement of their mortal torpedoes. To deepen our understanding of this passage, we must take a brief look at what has been dealt with on the preceding pages of the Gospel of Truth before touching upon some intertextual parallels.

To a large extent, the preceding pages of the Gospel of Truth deal with Error. It is described as mighty ${ }^{15}$ but at the same time it is clear that Error is temporary and not worth focusing on, "Therefore, ignore Error, since it thus has no root!"16 It is worth noting that the basis of Error is an ignorance that causes fear and turbulence. ${ }^{17}$ This immediately puts the knower on top, since that person has seen through Error and found emptiness and vanity in it rather than terrifying power. Therefore, it is logical that the knowers are described as rejoicing in the redemption through the power of the word. ${ }^{18}$ All this cheering up of the knowers is aimed at encouraging them when the preacher turns his attention to the concrete assaults of which that Error nevertheless is capable. Still, it exerts power over those who are undecided, ${ }^{19}$ and the dangers, which can result in the death of the preacher, are put in the foreground. ${ }^{20}$

Parent of Truth and of his messenger, even when entering the cosmic sphere and dying, is the dominating theme on the first pages of the Gospel of Truth. I take $\overline{\mathrm{N}} \times \mathbf{X}$ in $18.2 \mathrm{~g}$ 3 oa as a marker of the postponed subject $\overline{\mathrm{N}} \mathrm{l} \mathrm{l}$ with a cataphoric as well as an anaphoric meaning.

14 Gos. Truth NHC I,3 18.16-31.

15 Gos. Truth NHC I,3 17.14.

16 Gos. Truth NHC I,3 17.28-30. In the patristic era, KגTdфPON frequently means ignore rather than despise, see Lampe, Patristic Greek lexicon 726a. This line of thought was advocated for by Magnusson 2006, 78-79 and followed by Smith 2013, 79., "Ignore" seems to make much more sense in the context. A feeling like scorn does not sit well with the general message in the Gospel of Truth that one should focus on the joy of God's grace instead of cultivating destructive emotions.

17 Gos. Truth NHC I,3 17.9-14.

18 Gos. Truth NHC I,3 16.31-17.4.

19 Gos. Truth NHC I,3 17.30-36.

20 Gos. Truth NHC I,3 18.16-26. 
It seems as if the preacher of the Gospel of Truth wants to link the community's present concerns to the situation faced by the apostles after the Christ's crucifixion, thereby linking the present to a paradigmatic historical event, which increases the meaning of current events by joining them to prototypically significant figures of the past. For instance, 18.27-31 contains many similarities to 16.31-17.4. According to the Gospel of Truth, the first apostles rejoiced because through Christ's death they entered a mystical union with Christ that is described in terms of a mutual discovery. By referring to the Eucharist, a link is drawn between the first community after Christ's death and the community of the Gospel of Truth. Both rejoice, because they have found what they were searching for.

The rejoicing members of the community, probably both past and present, have merged with Christ through the Eucharist; therefore, one can say that the first embodiment of knowledge that Christ represented has multiplied into many embodiments of it. I propose that the community of the Gospel of Truth not only identified themselves with Christ and the first apostles, they also saw themselves as the continuation of redemption, on equal footing with Christ. Moreover, it means that Christ also had to go through a state of ignorance before being saved. This bold statement takes us to a discussion of to which textual universe the Gospel of Truth is related.

Normally, one should expect the spreading out to be a negative concept in Valentinianism, but when it is in union with Christ it becomes a multiplicity that transcends the division of the worldly realm. We might call it richness in unity.

At this point, it is fitting to reflect on what hermeneutical frame to adopt when interpreting the Gospel of Truth. The Pauline background is probable. In the second century $\mathrm{CE}$, the appropriation of Paul among the Gnostics caused proto-orthodox apologists seeing him as "the apostle of the heretics."21 In particular, the Valentinians played a predominant role as interpreters of Paul. ${ }^{22}$ Paul's cosmological understanding was particularly apt for Gnostic interpreters. ${ }^{23}$ Generally, in 1 Cor. $12: 12-27$, which is a key text when referring to the Pauline tradition, the community is described as the body of Christ. This imagery is central for the soteriology in the earliest Valentinian doctrine. Christ descends with the spiritual church that now is embodied by the

\footnotetext{
21 Pagels 1975, 157; 161-165.

22 Pagels 1975.

23 Denzey Lewis 2013, 53-84.
} 
Gnostics whose spiritual identities are constituted by the spiritual church. ${ }^{24}$ In the Pauline letters, however, to be a part of the body of Christ is not tantamount to being Christ. In the Gospel of Truth, as in other parts of the Valentinian traditions, the Pauline notion is pressed further. The following quotation from the Gospel of Philip could serve as a commentary on 18.26-31 of the Gospel of Truth: 25

God is a dyer. As the good dyes, which are called "true," dissolve with the things dyed in them, so it is with those whom God has dyed. Since his dyes are immortal, they become immortal by means of his colours. Now God dips what he dips in water. It is not possible for anyone to see anything of the things that actually exist unless he becomes like them. In the world man sees the sun without being a sun, and he sees the heaven and the earth and everything else without being these things: this is not how it is in (the realm of) the truth. Rather, having seen something of that place, you (sg.) became those things. You saw the spirit, you became spirit. You saw Christ, you became Christ. You saw [the Father, you] shall become a Father. Therefore: [in this place] you see everything and [do] not [see] yourself, but [in that place] you do see yourself and what you see you shall [become]. ${ }^{26}$

If we take the above passage at face value, it not only suggests that the knowers are saviors on the same level as Christ, they also become parents themselves and merge with the depth of the Godhead. This hypothesis is supported by the analysis of the following passages of the Gospel of Truth, to which we now turn.

\subsection{The Importance of the Collective}

In what follows after 18.31 of the Gospel of Truth, the author explains that even the Parent himself needed to enter a state of suffering in order to be known and loved.

Just as in the case of a person of whom others are ignorant, he wishes to be known and thus loved, for what did the All need if not such knowledge

\footnotetext{
24 This is a central aspect in what Thomassen 2006, calls the dialectics of mutual participation.

25 Gos. Phillip NHC II, 3.

26 Gos. Phillip NHC II, 3 61.12-35 (Transl. Thomassen 2006).
} 
of the Parent?27 - he became a mild, easy guide, appeared, and spoke the word as teacher. ${ }^{28}$

Just as in 18.11-17, the Parent, in the form of Christ, descends to reveal himself. It seems that even the Parent has to submit himself to the "rules of salvation." The boundaries between the Parent, Christ, and the knowers are blurred to the point of extinction. This supports the validity of the hypothesis that I put forward in the previous section. The knowers do not imitate Christ, they take on their identities as Christs themselves. After a short passage, ${ }^{29}$ in which the teacher, probably Christ, refutes those who are self-appointed as wise, the focus turns once again to the result of the victory of wisdom over foolishness.

After all these (events), the little children came to him as well, those to whom the knowledge of the Parent belongs. Having been strengthened, they had namely been acquainted with the outer manifestation of the Parent's face, they knew, they were known, they were glorified, they glorified, finally, ${ }^{30}$ it appeared in their intellect, the living book of the living, this that is written in the Parent's thought and mind and that from before the foundation of all things has been among his incomprehensible possessions, this that no one has authority to take, since it is ordained for the one who would take it up in order to be slain. ${ }^{31}$

Other translators have divided the text so that a new section starts with the appearance of the living book of the living. This seems odd, because then we have to interrupt a long asyndetic construction. If we instead construe the syntax as suggested in the translation above, we have a sequence that peaks when the "living book of the living" reveals itself in the intellect of the little children.

27 Both Orlandi 1992, 45 and Schenke 2001, 35 have had problems with the syntax in this sentence. Orlandi states that the syntax is unintelligible. I assume he thought that something was missing after 19.16. Schenke probably thought along the same lines. However, extending the period, as I have done, seems to solve the syntactical difficulties. Moreover, the elaborate style is common in the Gos. Truth. See, for instance, 17.4-18, 18.11-16, and 21.18-27.

28 Gos. Truth NHC I,3 19.10-20.

29 Gos. Truth NHC I,3 18.21-27.

30 We have reached the end of a series of asyndetic clauses. At the end of such chain, it is likely that the author wanted to stress something. Therefore, I have inserted the word "finally" in order to reproduce the syntax. In what way the asyndeton should be reproduced is a matter of taste, but not reproducing it would be a matter of under-interpretation/ translation.

31 Gos. Truth NHC I,3 19.27-20.6. 
These children have been acquainted with the face of the Parent. The outer manifestation of the Parent's face could refer to the holy kiss related to baptism but also to the birth into a new life of spiritual growth. The first stage of knowledge is to know yourself and your Parent. This is expressed in terms of mutual recognition and glorification. This closely resembles the mutual discovery in 18.26-31 that we have dealt with above. However, the Gospel of Truth also expresses a dimension of enlightenment that scholars have so far neglected: the knowledge that the community of spirituals expresses as a collective. It is through the embodiment in the community of knowers that one actualizes oneself as part of the living book of the living. In this light, the allusions to initiation rituals are fitting, but the full meaning of one's identity cannot be completely comprehended until everyone who is contained in that book has been actualized as a knower. This interpretation is supported by the following passages from the Gospel of Truth.

Since no one among those who had been entrusted with the salvation

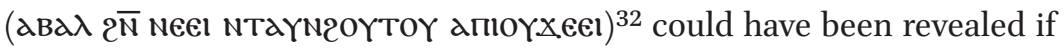
that book had not come forward, for this reason, the merciful, faithful Jesus became compassionate, accepting the sufferings even unto taking up that book. Because he knew that his death is life for many ${ }^{33}$ - just as in the case of a will before it is opened - the fortune of the deceased master of the house is concealed; and just as in the case of the All that was concealed, since the Parent of the All is invisible, because he is one from himself, the one from whom everything continually ${ }^{34}$ comes forth. For this reason, Jesus appeared, clothed himself in that book, was nailed to a tree, and published the edict of the Parent on the cross. O with such great teaching he draws himself down to death, although life eternal clothes him! ${ }^{35}$

32 Normally, the verb nąTe has been rendered as "believe" instead of "entrust." However, "believe" does not work as well grammatically as "entrust," since the form of the verb is reflexive N20YToY. Thomassen 2002, 106 was on the same track as me but in a freer form. In Magnusson 2006 137"entrusted" was used, and an embryo of the line of thought that will be developed in this article was argued for Magnusson 2006, 46 .

It is interesting to read this clause in relation to John 11:47-53, where Jesus's death is related to the hostile actions of the Jewish and Roman authorities. However, this kind of assumed intertextuality is speculative and not necessary for the present study.

34 "Continually" renders the Coptic "habitual." See discussion in the main text.

35 Gos. Truth NHC I,3 20.11-30. 
This passage requires some intertextual and philological remarks. The verb that lies behind "entrusted" is NąTe. It could be translated as either "believe" or "entrust," but because the form that we have in this text, N20YToY, is reflexive, "entrusted" is preferred. The only occurrence that I have found of the reflexive form of this verb appears in the Akhmimic version of the First Epistle to the Corinthians by Clement of Rome 43:1. There the verb refers to those who have been entrusted with "the work in Christ (oi $\dot{\varepsilon} \nu$ Xp $\theta \varepsilon \circ 0$ हैpyov)." The context in which this expression of 1 Clement occurs is interesting for our discussion as well. In the preceding chapter, Clement discusses the way in which Christ had the mission to save the apostles who, in turn, had to continue the work of Christ. Then this continuous labor is transferred to the first bishops and to other Christians.

Although we cannot be certain that this intertext was relevant for the author of the Gospel of Truth, the similarities when it comes to semantics and context are striking. The work of salvation was not completed by Christ, but it started a process of continual enlightenment that spreads through all those who become enlightened. If we consider that the meaning of a text in a book changes when other texts are added, the one who saves someone else discovers new dimensions of his or her own identity. Therefore, it is likely that the preacher of the Gospel of Truth was influenced by the pattern of 1 Clement 42-43 when the metaphor of "the living book of the living" was chosen.

As noted in note twenty-nine above, I have tried to make sense of the use of the Coptic term for "habitual." As far as I can see, other translations, including my own earlier attempts, have failed to make sense of its usage. On the basis of the suggested interpretation of the text that underlines the spreading of knowledge on the knowers of different ranks and generations, the use of "habitual" is quite natural. Salvation is an ongoing event that does not stop until everyone who is destined to be included in the "living book of the living" has actualized their true and complete identity. My interpretation is supported by a similar usage of "habitual" in another passage of the Gospel of Truth:

Since he (Christ) is the revelation of the Parent, and the uncovering of him to his Aeons, he revealed his secret and unloosened himself. For who is the one who contains if not the Parent himself? All (MdeIT NIM) ${ }^{36}$ are his emanations. They have known that it is from him that they have come

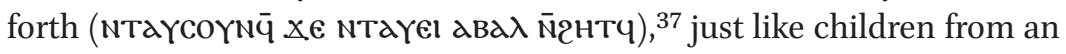

36 I follow an oral suggestion made by Louis Painchaud obtained at the university of Bergen, 2003. The literal rendering "all ways" make less sense.

I have tried to reproduce the emphatic construal and chosen the local dimension. 
adult. Nevertheless, they knew ${ }^{38}$ that they had not yet received form or name, which the Parent continually begets (d)a quice) ${ }^{39}$ everyone. Then, when they receive form by his knowledge - otherwise, they would be in him without knowing him, but the Parent is complete, he knows everything that is in him when he wishes, he reveals whoever he wants by granting form and name to himself and even continually names (c)ayt PEN NEY $)^{40}$ him..$^{41}$ And he causes him to come into being for the sake of those who have not yet come into being. They are ignorant of the one who has fashioned them. Now, I do not say they are nothing, those who not yet have come into being; rather, they exist in him who will wish, so they come into being when he wishes. ${ }^{42}$

The teaching that Christ embodies is the living book that consists of the individual knowers. However, as we will see in the following passages, the deepest meaning of the identity of every knower can only be expressed by the actualized salvation of the entire community of knowers. Hence, every knower and those who are appointed to be saved by it are interdependent. The above interpretation of the process of salvation is strongly supported when we continue reading the following passages from the Gospel of Truth.

\section{$2.4 \quad$ The Mutual Belonging}

In the previous passages of the Gospel of Truth, the climax was reached when the Savior descended and actualized the union with those who recognized him. Now the focus turns to a description of how the Savior resurrects and leads those who belong to him and who, in turn, resurrect and lead others.

About themselves they receive instruction, as they recover themselves from the Parent by returning to it. Because the completion of the All is in the Parent, it is necessary for the All to go to it. Then, as anyone comes to know, he continually ${ }^{43}$ receives those who belong to him, and he continually ${ }^{44}$ draws them to himself. For the one who is ignorant is

38 меүсаүме ммач пє, "Nevertheless, they knew ..." The preterite functions as a comment to the main line of thought. I have tried to reproduce that function by using "nevertheless."

39 By "continually" I try to render the habitual construal.

40 By "continually," I have tried to reproduce the habitual construal.

41 I have chosen "him," because it might refer to Christ. See the discussion in the main text. A reasonable option would be "himself," referring to the Parent.

42 Gos. Truth NHC I,3 27.5-28.3.

43 "Continually" is an attempt to render the Coptic term for "habitual."

44 "Continually" again is an attempt to render the Coptic term for "habitual." 
in need, and what he lacks is great, since he lacks what would make him complete. ${ }^{45}$

In the above passage, some interdependent aspects of salvation are mentioned. By reading the book, the knower also learns about himself or herself. Encountering others is a way to become enlightened about oneself and to become enlightened by and about others, but it is no philosophical enlightenment. The enlightenment is linked to the resurrection or the return to the Parent of Truth. Much of this was touched upon in 19.27-20.6 in which the appearance of the living book of the living was the climax of a revelatory process, but here it becomes more explicit. At the same time, the necessity of returning to the Parent by bringing others from darkness comes into the foreground more than before.

Logically enough, the text turns to address the duty of the newborn spiritual person to raise others from death to life and thereby become a savior who leads others back to the Parent. In light of this, for the first time, I dare to say, the statement that "the one who knows receives those who belong to him" has been interpreted in a meaningful way. The saving of others gives a new meaning to one's own existence and thus is also a part of self-acquaintance.

Because the completion of the All is in the Parent, and it is necessary for the All to go to it, and each one has to receive those who belong to him, which the Parent had inscribed in advance, having prepared it to give to those who had come forth from the Parent, those whose names the Parent already knew from the beginning, in the end they were called. ${ }^{46}$

This passage could be read as a generally dogmatic statement: the Parent has inscribed everyone from the beginning. Although such a reading would catch one important thought, we should read it in the intra-textual context of the Gospel of Truth. According to this and the previous passages, there are persons who belong to the knower. In the same way as Christ, the knower, leads others from death to life, they can do the same, since they have been called by the Parent and led by a savior. However, in light of the following sections, I suggest that this passage paves the way for a discussion of the problem that the missionary faces. Not everyone responds positively to the message. Read in this way, the final call of everyone who is inscribed from the beginning ensures the knower that she or he is in the right place in history, because the Parent has

45 Gos. Truth NHC I,3 21.3-18.

46 Gos. Truth NHC I,3 21.18-27. 
called everybody at the right moment. It also comforts the knower that nobody who belongs to life will forever remain in the sphere of death.

Because it is one who knows whose name the Parent has called (20)

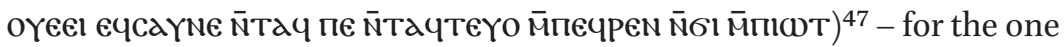
whose name has not been spoken is an ignorant - how else would someone listen unless his name has been called? For the one who is ignorant to the end is a delusion of oblivion, and he will vanish with it. If it were otherwise, why do such miserable persons not have voice[less $]^{48}$ names? ${ }^{49}$

The experience that not everybody responds positively to the message is introduced. The therapy of fear is a central issue in the Gospel of Truth, so those who fail to respond in the right manner cannot be condemned. Harshness and revenge belong to the sphere of Error and are not worthy of the bringers of the Parent's joy. Instead, those who fail to grasp the truth of the Parent are held to belong to Error and, in the end, will vanish with it.

The predestination that is obvious in this passage of the Gospel of Truth neither results in passivity nor condemnation of others. You are responsible for others and thus should work on your own and other's inner growth while remaining aware that those who belong to salvation will receive it and, in this way, add meaning to your existence. Fear is done away with, because you know that everyone who belongs to the Parent will be called and respond in the manner described in the following passage.

Consequently, such a person, when he knows, he is from above. When they call him, he hears, responds, and turns to the one who is calling him, goes to him, and he understands. Because when they call him in such way, he knows, does the will of the one who has called him, and wants to please him, he receives rest, and the name of the One becomes his own. Whoever knows in such a way understands from where he has come and where he will go. He understands just like someone who after having become drunk shakes off his drunkenness. ${ }^{50}$

47 "Because it is one who knows whose name the Parent has called." To construe the syntax as a cleft sentence was suggested to me by Stephen Emmel. This solves the problem with $2 \omega \mathrm{c}$, which should be followed by a main clause and have a causal function.

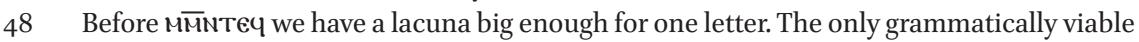
reconstruction is $€$, which results in the suggested translation.

49 Gos. Truth NHC I, 3 21.28-22.2.

50 Gos. Truth NHC I,3 22.2-22.18. 
Out of the preceding discussions, it is expected that in this passage we frequently find habitual constructions. In the translation, I have marked the verbs in the habitual with italics. The habitual underscores the ongoing process. According to my interpretation, the one who is from above responds to two kinds of calls. One is expressed in the perfect tense, пентдгмоүте дрдy, "the one who has called him." ${ }^{51}$ I assume this call was from the Parent, and it is logical that it is to the Parent that the knower responds in the latter part of the passage.

The continuing response in the earlier part of the passage might refer to responding to those who are in need of oneself. In light of this, it is natural that the passage that ends with the imagery of the knower who receives enlightenment shifts into a description of how the knower is transformed into a savior who leads others out of ignorance. Thus, the knower's name is recognized by the Parent as well as of the one who receives enlightenment. In the next passage, we see in what manner the terminology that frequently has been interpreted as referring to Christ only might also refer to the knower in the new role as savior.

When he had returned to himself, he set right those things that belong to him, reclaimed many from Error, went before them to the ways from which they had swerved when they accepted Error because of the depth of him who surrounds everything, while nothing surrounds him. It was a great wonder that they were in the Parent, though not knowing him, and that they were able to come forth alone, since they were not able to comprehend themselves, nor could they know the one in whom they were. For if his will had come forth from him -52

The passage ends abruptly (probably a line or so is missing at the end of the passage) but the main content is clear enough. The one who has risen from ignorance and who leads others out of Error refers to Christ, but in this context even more to the knower. In the next passage, the dimension of interdependent identities that I have touched upon already is much more outspoken; moreover, we will learn that the salvation that the saved savior actualizes has a soteriological significance for the aeons in the Fullness as well.

51 Gos. Truth NHC I,3 22.10-11.

52 Gos. Truth NHC I,3 22.18-35. 


\subsection{Saving Every Aeon!}

It is easily assumed that enlightenment is an affair between only the knower and the Godhead, but we have already seen how the Gospel of Truth displays more dimensions to salvation than that. The complete salvation includes the aeons in the Fullness as well. This line of thought is central in the following passages from the Gospel of Truth.

For he revealed it, and they knew in harmony with all its ways, this is the knowledge of the living book that he at the end revealed to the aeons, to his texts. ${ }^{53}$ When it becomes revealed. They ${ }^{54}$ speak as texts that are not for voicing, ${ }^{55}$ nor do they need sound for someone to read them out and think of foolishness, but rather they are texts of truth; they are those $\mathrm{e}^{56}$ that pronounce themselves by knowing as one $t[\text { hought }]^{57}$ that is complete. As for each text, they are just like a book that is complete. They have written themselves through the unity that the Parent had written (for) the aeons that through these, his texts, they would know ${ }^{58}$ the Parent. ${ }^{59}$

Through each knower's life, a perfect text that the Parent wrote in advance is actualized. It is very central that these texts cannot be written down or pronounced in ordinary fashion. They are embodied truths and express themselves through actions of redemption of others. This is an interesting topic that I am currently devoting an entire article to.

A complete book cannot lack chapters. Thus, everyone who is inscribed in advance will be saved. Again, the collective perspective is underscored, because no text in the book will receive its complete meaning before the entire

53 Nic2eel can be translated as "texts" or "letters." As when the knowers understand their own identities, it entails that they understand their meaning in life as saviors, I prefer translating with texts, rather than with letters. Texts have meaning, whereas letters do not.

54 elo)exe has to be eү()exe.

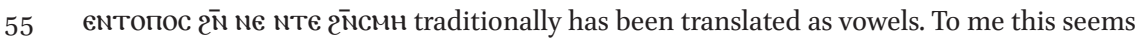
unwarranted. In 22.1, we have voiceless names, and here the same topic recurs. The ultimate truth cannot be written down or spoken in ordinary ways. The truth has to be embodied, and is expressed in action. It is a neglected theme of study as for the Gos. Truth, and I am currently devoting another article to this topic.

$56 \quad$ I try to render an emphatic construction with the extraposited $\bar{N} T d \gamma$.

57 The word in the manuscript is $\mathrm{m}$, , which means truth. This word is normally spelled мнє in the Gos. Truth. I have chosen to amend it to $\mathrm{me} €$, but either way works well and does not make a huge different regarding the interpretation.

$5^{8}$ edcoYwn, "they would know." I take it as a Lycopolitan form of the future.

59 Gos. Truth NHC I,3 22.35-23.18. 
book is actualized. Now the aeons also prosper from the actualization of the living book of the living. According to the myth of the fall of Wisdom, Sophia, it is fitting that, in the next section, that she is enlightened through the living book of the living.

As his Wisdom meditates upon the Word, his Teaching utters it, his Knowledge has become revealed. His Forbearance is a crown upon him as his Joy is in harmony with it. His Glory has exalted him. His Image has revealed him. His Repose has embraced him. His Love has embodied him. His Faith has guarded him. ${ }^{60}$

The appearance of a royal figure is what we would expect based on the analyses in this article. In the deepest sense, it is the Parent that is embodied. The pattern reminds us of the prophet king well-known from Jewish literature. ${ }^{61}$ By embodiment of the innermost of the Parent, the collective of saviors spreads enlightenment not only to themselves but also to the entirety of aeons.

I could easily continue going through the Gospel of Truth and list examples of when the suggested interpretations that I have put forward are supported, but the scope of this paper is limited, and I hope that following this line of thought through a part of the Gospel of Truth has made it possible for the reader to evaluate my proposed interpretations. There are only two kinds of beings in the Gospel of Truth: the knowers and the ignorant. The urge for complete collective salvation would have led the knower to treat others as potential knowers until the end. The truth is a way, and the call might be delayed to the final movement, according to the wisdom of the Parent of truth. ${ }^{62}$ My analysis of how determinism functions even in a text that focuses on ethical growth and missionary zeal goes well with the nuanced view of determinism expressed, for instance, by Williams. ${ }^{63}$

Thus, we only have to deal with two categories of beings. On the one hand are those with a capacity for spiritual enlightenment who will be saved in the end. On the other hand, are those who only exist temporarily. This fits well

6o Gos. Truth NHC I,3 23.18-32.

61 See Meeks 1967 for multiple references.

62 Gos. Truth NHC I,3 18.17-21; 21.30.

63 Williams 1996, 189-211. 
with the description of Eastern Valentinianism developed by Thomassen, but the line of thought that I have put forward through this intra-textual analysis of the Gospel of Truth is completely new. ${ }^{64}$ It stresses a close relationship between our text and the Gospel of Philip that has been hitherto neglected. The knowers are held to be saviors on equal footing with Christ. As a collective, they constitute the Parent of truth who, by means of the spiritual church, restores and raises the Fullness to the complete knowledge that comes from the process of gradual and collective enlightenment.

This is a much bolder kind of soteriology and anthropology than we encounter in non-Gnostic versions of Christianity. In this respect, I side with April DeConick, who has stressed that in Gnosticism the knowers boldly claim to be God. ${ }^{65}$ This perspective might shed new light on the Treatise of the Resurrection as well as on the Tripartite Tractate, but this is something that exceeds the scope of this article.

What is advocated for in the Gospel of Truth is an ideal, probably influenced by the preacher's context. All are invited to take part in the work of salvation, and to be an enlightened one does not seem to be something for a small minority of educated philosophers only. On the contrary, salvation is a fruit of the collective effort, directed in the deepest sense by the Parent of Truth, something that will restore and enlighten the Fullness as well as every knower. Based on this analysis, I aim to broaden the investigation and include other Valentinian and non-Valentinian texts in order to compare the Christology and soteriology that I have depicted in this article.

\section{Bibliography}

Arai, Sasagu. 1964. Die Christologie des Evangelium Veritatis: Eine Religionsgeschichtliche Untersuchung. Leiden: Brill.

DeConick, April D. 2016. The Gnostic New Age: How a Countercultural Spirituality Revolutionized Religion from Antiquity to Today. New York: Columbia University Press.

Denzey Lewis, Nicola. 2013. Cosmology and Fate in Gnosticism and Graeco-Roman Antiquity: Under Pitiless Skies. Nag Hammadi and Manichaean Studies 81. Leiden: Brill.

Fecht, Gerhard. 1961. "Der erste 'Teil' der sogennanten (16:31-22:20)." Orientalia 30:371-39o.

64 Thomassen 2006.

65 DeConick 2016. 
Fecht, Gerhard. 1962. "Der erste 'Teil' der sogennanten Evangelium Veritatis 16:3122:20." Orientalia 31:85-119.

Fecht, Gerhard. 1963. "Der erste Teil der sogennanten Evangelium Veritatis (16:3122:20)." Orientalia 32:298-335.

Good, Deirdre J. 1988. "Gender and Generation: Observations on Coptic Terminology, with Particular Attention to Valentinian Texts." Pages 23-40 in Images Of The Feminine in Gnosticism. Edited by Karen L. King. Philadelphia: Fortress Press.

Helderman, Jan. 1984. Die Anapausis im Evangelium Veritatis: eine vergleichende Untersuchung des valentinianisch-gnostischen Heilsgutes der Ruhe im Evangelium Veritatis und in anderen Schriften der Nag Hammadi-Bibliothek. Nag Hammadi Studies 18. Leiden: Brill.

Magnusson, Jörgen. 2006. Rethinking the Gospel of Truth: A Study of Its Eastern Valentinian Setting. Uppsala: Uppsala University Press.

Magnusson, Jörgen. 2016. "Beyond Righteousness and Transgression: Reading the Gospel of Judas and the Gospel of Truth from a Cosmic Perspective." Pages 167193 in Philosophy and the End of Sacrifice: Disengaging Ritual in Ancient India, Greece and Beyond. Edited by Anna-Pya Sjödin \& Peter Jackson. Sheffield: Equinox Publishing Ltd.

Meeks, Wayne A. 1967. The Prophet-King: Moses Traditions and the Johannine Christology. Leiden: Brill.

Nagel, Peter. 1966. "Die Herkunft des Evangelium Veritatis in Sprachlicher Sicht." Orientalistische Litteraturzeitung 61:5-14.

Orlandi, Tito. 1992. Evangelium Veritatis. Brescia: Paideia.

Pagels, Elaine H. 1975. The Gnostic Paul: Gnostic Exegesis of the Pauline Letters. Philadelphia: Fortress Press.

Smith, Geoffrey. S. 2013. Constructing a Christian Universe: Mythological Exegesis of Ben Sira 24 and John's Prologue in the Gospel of Truth. Pages 64-84 in Jewish and Christian Cosmogony in Late Antiquity. Edited by Lance Jenott and Sarit Kattan Gribetz. Tübingen: Mohr Siebeck.

Standaert, Benoit. 1976. "L'Évangile de la Vérité: Critique et Lecture." New Testament Studies 22:243-275.

Tite, Philip L. 2009. Valentinian Ethics and Paraenetic Discourse: Determining the Social Function of Moral Exhortation in Valentinian Christianity. Leiden: Brill.

Thomassen, Einar. 2006. The Spiritual Seed: The Church of the "Valentinians." Nag Hammadi and Manichaean Studies 6o. Leiden: Brill.

Williams, Michael A. 1996. Rethinking "Gnosticism": An Argument for Dismantling a Dubious Category. Princeton: Princeton University Press. 